\title{
The Impact of Economic Attitudes on Natural and Social Corporate Responsibility - A Comparative Study of Lithuania and Slovenia
}

\author{
Zlatko Nedelko', Valentina Peleckiene ${ }^{2}$, Kestutis Peleckis ${ }^{3}$, Kestutis K. Peleckis ${ }^{4}$, Giedre \\ Lapinskiene $^{5}$, Vojko Potocan 6
}

${ }^{1,6}$ University of Maribor

Razlagova 14, SI-2000 Maribor, Slovenia

E-mail. ${ }^{1}$ zlatko.nedelko@um.si, ${ }^{6}$ vojko.potocan@um.si

2,3,4,5 Vilnius Gediminas Technical University

Sauletekio av. 11, 10221 Vilnius, Lithuania

E-mail. ${ }^{2}$ valentina.peleckiene@vgtu.lt; ${ }^{3}$ kestutis.peleckis@vgtu.lt; ${ }^{4}$ k.peleckis@vgtu.lt; ${ }^{5}$ giedre.lapinskiene@vgtu.lt

cross $^{\text {ref }}$ http://dx.doi.org/10.5755/j01.ee.30.3.21119

\begin{abstract}
This paper reports on research that examines the state of corporate social responsibility (CSR) and the impact of economic attitudes on natural and social CSR in Lithuania and Slovenia. The study exposes CSR and organizational behavior theories and analyzes answers from 159 Lithuanian and 183 Slovenian business students considered as future employees. The authors established a model to examine the impact of economic CSR - considered through a "primary concern for economic results" and "devoting resources for CSR" to "natural CSR" and "social CSR." In Lithuania interest in social CSR prevails, while in Slovenia interest is focused on natural CSR. The economic aspect of CSR is poorly appreciated in both countries. Associations between CSR aspects reveal that favoring economic results has no significant influence on natural and social CSR in the Lithuanian sample. In the Slovenian sample there is a significant and negative association between the concern for economic results and natural and social CSR. A positive and significant impact of devoting resources to natural and social CSR in both countries exists, but the impact is stronger for Slovenia than Lithuania. Devoting resources contributes more to a concern for social rather than natural CSR in both samples. Economic CSR explains significantly more variance in social CSR than in natural CSR. The findings could help improve and develop CSR behavior in organizations and among their future employees. They could also benefit higher education organizations and society.
\end{abstract}

Keywords: Natural Environment, Social Environment, Economic Environment, Corporate Social Responsibility, Slovenia, Lithuania.

\section{Introduction}

Organizations' interest in their responsibility to society beyond making profits for shareholders, and in harmonizing their operations in line with societal demands, has been growing from the 1960s (Dunlap \& Mertig, 1990). Since then, organizations have implemented corporate social responsibility (CSR) to effectively manage their natural (environmental), social, and economic obligations in modern society (Aguinis \& Glavas, 2012; Carroll, 1999; McWilliams \& Siegel, 2000).

Several conceptualizations of CSR in organizations (Aguinis \& Glavas, 2012; Carroll, 1999; Waddock \& Graves, 1997) provide guidance for "conceptual frameworks and methods for addressing the management, organization, and societal challenges in CSR practices" (Wang, Tong, Takeuchi, \& George, 2016, p. 535). According to Aguinis and Glavas (2012), available theories and fundamental knowledge of CSR enable organizations to be proactively committed to natural and social challenges to their stakeholders. However, organizations' responsibility to shareholders' values (Aguinis \& Glavas, 2012; Carroll, 1999; Davis, Whitman, \& Zald, 2008; McWilliams \& Siegel, 2000), and specifics in CSR implementation (Carroll \& Shabana, 2010; Schrempf-Stirling, Palazzo, \& Phillips,
2016; Waddock \& Graves, 1997) have not been fully researched.

This lack of research is problematic because the presence of opposing economic theories (Crifo \& Forget, 2015; McWilliams \& Siegel, 2000) has led to a distinctive research of the economic aspects of CSR (Kitzmueller \& Shimshack, 2012; Waddock \& Graves, 1997). A broader dissemination of CSR's economics requires greater attention and expertise from academics and practitioners to balance CSR's goals in short- and long-term organizational decisions (Crifo \& Forget, 2015). In addition, a consideration of the implementation of characteristics has revealed organizational, institutional, and circumstantial reasons for different situations of CSR, and answered calls from academics and international organizations for the development of specific actions in CSR practices (Carroll \& Shabana, 2010; Slaper \& Hall, 2011).

Novelty of the research - the novelty of the research is revealed through multi-disciplinary, multi-dimensional, and multi-conditional analysis of CSR, which could influence the development of the theoretical and practical issues of CSR (Aguinis \& Glavas, 2012; Wang et al., 2016). In contrast to previously published reviews, our study integrates environmental, managerial, organizational, and behavioral theories (Elkington, 2004); environmental, 
social, and economic initiatives and arguments (Carroll \& Shabana, 2010); and the impacts of organizational, institutional, and conditional drivers on CSR (Davis et al., 2008; Slaper \& Hall, 2011). The above-mentioned approaches enable an analysis of the economic aspects associated with natural and social CSR.

Object of the research - empirical and theoretical studies of CSR among future employees in Slovenia and Lithuania. Both countries have recorded significant improvements in the development of CSR, under diverse conditions. To ensure the continuation of the current pace of CSR development, we need to develop appropriate CSR behavior among current and future employees.

Aim of the research - after identifying the main and commonly used theoretical and empirical studies of disciplines, dimensions, and conditions of CSR, the authors have shaped solutions for broader studies of CSR among future employees in Lithuania and Slovenia in order to address their readiness for CSR. To achieve this aim, the study has set the following tasks. First, a review of the theoretical research of CSR's aspects enables us to form guidelines and a research model for further research. After conducting empirical research on the CSR situation and the association between aspects of CSR, this study concludes with proposals for the theoretical and practical application of CSR's development among organizations, the educational sphere, and entire society.

Problem of research - what are the current states of CSR among future employees in Lithuania and Slovenia? What are the main differences between the recognized states of CSR in both countries? What is the impact of business students' economic attitudes on their natural and social CSR.

Several CSR studies show congruence on fundamental knowledge relating to the key factors (Waddock \& Graves, 1997), development patterns (Carroll, 1999), and implementation trends (Ralston et al., 2011; Wang et al., 2016) of CSR. Other scholars have written literature reviews addressing the impacts of prevailing internal and external organizational circumstances for CSR (Carroll \& Shabana, 2010; Schrempf-Stirling et al., 2016; Waddock \& Graves, 1997). This study differs by conducting a comparative analysis of CSR's situation in Lithuania and Slovenia, following the recommendations of Furrer et al. (2010) about a broader investigation of CSR's situations among the EU countries; Vveinhardt and Andriukaitiene (2014) on the necessary development of CSR in Lithuania; and Potocan, Nedelko, Peleckiene, and Peleckis' (2016) suggestions for a comparative analysis of CSR between the EU countries with transition footprints. We focused on business students, since existing studies have revealed mainly organizational stakeholders' readiness for CSR. Little evidence indicates how new generations of future employees are prepared to participate in CSR development, or understand and consider CSR. This issue is of huge importance, since millennials' concern for CSR is not one of their top priorities (Ng, Schweitzer, \& Lyons, 2010). Accordingly, this issue needs considerable attention in order to ensure further improvement of CSR, together with an improvement of millennials' readiness for CSR. Among the various aspects of CSR, less considered and explained is the potential negative, positive, or neutral effect of the economic aspect on natural and social CSR (Aupperle, Carroll, \& Hatfield, 1985; Crifo \& Forget, 2015; Windsor, 2006) exposed in studies of different roles of economic CSR in the EU organizations (Furrer et al., 2010), the priority given to profit over CSR in Lithuanian organizations (Vasiljeviene and Vasiljev (2005), and the weak impact of the economic aspect on CSR in Slovenian organizations (Potocan et al., 2016). Thus, this study responds to calls by Furrer et al. (2010) to explain the differences in the effect of economics on CSR among the EU organizations (Furrer et al., 2010; Vasiljeviene and Vasiljev, 2005), in order to analyze the prevailing profit orientation in Lithuanian organizations and (Potocan et al., 2016) to explain the weak impact of economics on CSR in Slovenian organizations.

As the field of CSR has evolved, academics such as Stern (2000) and Aguinis (2011), and several special issues of leading journals such as the Academy of Management Journal (Wang et al., 2016) and Frontiers in Psychology (Glavas, 2016), have revealed the need for explanations of the associations between behavior and CSR. Behavioral studies of CSR address several specific conceptual, methodological, and disciplinary issues, such as the implications of different behavior theories (Ajzen, 2005; Glavas, 2016), responsible behavior on different organizational levels (Carroll \& Shabana, 2010; Davis et al., 2008), and intersections between stakeholder' beliefs, values, attitudes, and behavior (Ajzen, 2005; Glavas, 2016) under CSR. This study focuses primarily on the direct influence of future employees' attitudes toward economic CSR on their attitudes toward natural and social CSR in the values-attitudes-behavior chain (Davis et al., 2008; Stern, 2000).

Research methods/design/approach following Podsakoff, MacKenzie, and Podsakoff (2012) the authors of this study have modified the findings related to the proper application of theories from different disciplines to make them fit the specific objectives of the present contribution. In line with the research aims, the authors established a research model to examine the effect of economic attitudes regarding CSR, considered through a "primary concern for economic results" and "devoting resources for CSR" on "natural CSR" and "social CSR." The calculations of the results are based on 159 answers from Lithuanian business students and 183 answers from Slovenian business students considered as future employees. In the empirical part, we used elements of descriptive statistics, bivariate correlation analysis, and independent samples t-test using SPSS 23.0, and the structural equation modeling approach using AMOS 18.

\section{Theoretical Background and Hypotheses}

\section{Corporate Social Responsibility}

Over the past six decades, organizations have been using CSR practices to reduce their business and legal risks and advance their ability to match the requirements of modern society (Aguinis \& Glavas, 2012; Carroll \& Shabana, 2010; Wang et al., 2016). A detailed overview of the CSR concept and its triple bottom line model (Aguilera, Rupp, Williams, \& Ganapathi, 2007; Elkington, 2004; Wang et al., 2016) are beyond the scope of this article. For the purposes of this study, the authors briefly outline the variables of interest for the development of the research hypotheses. 
Scholars have studied the conceptualization of this model through research (Dahlsrud, 2008; Elkington, 2004; Glavas, 2016) on different socially constructed CSR (Aguinis \& Glavas, 2012; Davis et al., 2008; Elkington, 2004); individual aspects of CSR (Reinhardt, Stavins, \& Vietor, 2008); and the importance of CSR for stakeholders and broader society (Stern, 2000). They have also studied the findings on decision making regarding CSR (Aguinis \& Glavas, 2012; Egri \& Herman, 2000) and the impact of CSR on organizational outcomes (Aguinis \& Glavas, 2012; Aupperle et al., 1985; Waddock \& Graves, 1997), which provide additional guidance for the operationalization of CSR in practice.

The findings on conceptualizations of CSR in several contexts for business are more varied (McWilliams \& Siegel, 2000). The increasing importance of CSR's specifics has been highlighted through studies of heterogeneous motives (Campbell, 2007), interests for implementation (Schrempf-Stirling et al., 2016; Waddock \& Graves, 1997), and implementation in diverse environments (Carroll \& Shabana, 2010; Dunlap \& Mertig, 1990).

To avoid confusion, due to the available conceptualizations of CSR (Carroll, 1999; Dahlsrud, 2008), the authors use the definition of CSR offered by Aguinis (2011, p. 855): “Context-specific organizational actions and policies that take into account stakeholders' expectations and the triple bottom line of economic, social, and environmental performance."

Organizational CSR's initiatives are influenced and implemented by stakeholders; this extended consideration of CSR with the behavior dimension (Aguinis \& Glavas, 2012). For example, Podsakoff et al. (2012) and Campbell (2007) have called for additional study of CSR-related behavior issues, such as longitudinal analysis (Schultz et al., 2005; Windsor, 2006); multi-level research (Aguilera et al., 2007; Glavas, 2016); and development of CSR among business students (Furrer et al., 2010; Kemmelmeier, Krol, $\&$ Kim, 2002). Authors have put forward a research agenda about the perception of business students as future organizational stakeholders ( $\mathrm{Ng}$ et al., 2010).

\section{Corporate Social Responsibility in Lithuania and Slovenia}

International studies, such as the one by Furrer et al. (2010) and the UN (2017), have revealed differences in CSR's situation between organizations from several cultural, economic, and political environments. Although most of the extant literature is linked to the CSR situation in most developed countries (Dunlap \& Mertig, 1990; Wang et al., 2016), increasing interest has been shown in CSR in countries with specific development experiences, such as former transition countries (Furrer et al., 2010; Vveinhardt \& Andriukaitiene, 2014). Moreover, development documents of the EU (EC, 2018a, 2018b) have revealed the need for more studies to understand the CSR situation in the EU member states with a transition legacy.

The European Union (EC, 2018a, 2018b) and the United Nations (2017) have reported significant development of CSR in post-transitional countries in Europe, and emphasized the results achieved by CSR in Slovenia and Lithuania, among others. Understanding how these two countries, with a diversified socialistic and communistic legacy (from 1945 to 1990), different economic situations (after joining the EU in 2004), and different development trends of CSR, can attain comparable development of CSR, guides us in selecting and studying CSR among organizations from Slovenia and Lithuania.

Thus, this review covers the lack of broader evidence about the characteristics and patterns of CSR's situation and their comparable analysis of organizations from Lithuania and Slovenia as samples of transitional countries with specific developmental experiences (Ericson, 1991; Potocan et al., 2016).

The European Commission (EC, 2018a, p. 10) has recorded substantial improvement in the development of CSR in Lithuanian organizations in a longer term perspective from 2001 to 2017. Lithuanian organizations have recorded stable progress in implementing CSR, when limited progress was achieved in improving the structural preconditions for CSR in society. Regardless of the progress achieved, empirical studies indicate several open issues regarding CSR's implementation in organizations and society (Salciuviene, Hopeniene, \& Dovaliene, 2016). For example, Vasiljeviene and Vasiljev (2005) revealed that organizations in Lithuania favor profits over CSR and find economic CR more important than natural and social CSR. Vveinhardt and Andriukaitiene (2014) reported the development of CSR in Lithuanian organizations, coupled with their need to promote CSR in organizational practices. Finally, Dagiliene, Leitoniene, and Grencikova (2014) argued that several organizations lack understanding of CSR's importance in business.

The development, implementation, and long-term sustainability of CSR in Slovenian organizations over the past 30 years has improved (EC, 2018b, p. 11). The results of the European Commission Growth Survey (EC, 2018b, p. 10) show that the implementation of CSR in Slovenian organizations has increased since 2011, but the preparation and adoption of structural reforms for further sustainable development have been delayed. Empirical studies indicate several important areas for improving CSR in these organizations. For example, Jelovac, Van Der Wal, and Jelovac (2011) have called for the improvement of CSR in public administration, and Potocan et al. (2016) have revealed structural gaps in CSR's situation in Slovenian companies.

\section{Socially Responsible Behavior}

The CSR literature has presented diverse behavior theories that analyze the physical action and observable emotions associated with psyche and other personality traits, temperament, and cultural characteristics of individuals, as planned behavior and behaviorism (Ajzen, 2005; Dunlap \& Mertig, 1990; Eagly \& Chaiken, 1998). Empirical studies have confirmed that the values-attitudesbehavior chain importantly predicts organizational CSR (Aguilera et al., 2007; Stern, 2000). In the theoretical flow of values-attitudes-behavior causal chain of CSR, considerable attention has been paid to attitudes (Eagly \& Chaiken, 1998; Schwartz et al., 2012; Wood, 2000) through studies on attitudes, correlations between different attitudes, and their impact on other links in the behavior chain (Ajzen, 
2005; Stern, 2000). Following the tradition of social psychology (Eagly \& Chaiken, 1998; Schwartz et al., 2012), the authors treat attitudes as "psychological responses to a person, an object, to a situation, to society and to life itself, that generally influence a person's behavior and actions" (Eagly \& Chaiken, 1998, p. 291). In line with the aims of their study, the authors presented the following CSR attitudes.

Attitudes toward natural environment express humans' orientation toward the relative importance of: (1) plants, animals, or the entire earth (Carroll \& Shabana, 2010; Schultz et al., 2005); (2) prevention of negative consequences in human-environment interactions (Stern, 2000); and (3) the adoption of specific environmental practices in society (Aguilera et al., 2007; Schultz et al., 2005).

Enforcement of sustainable development in modern society (Elkington, 2004) decisively affects the development of these attitudes toward the sustainable behavior of stakeholders in organizations (Glavas, 2016). Academic and practitioners' studies have revealed the importance of contentual, contextual, and situational factors (Carroll, 1999) in shaping stakeholders' attitudes in and among organizations in different environments (Kemmelmeier et al., 2002). Less explained are the reasons for the situation of these attitudes among future organizational stakeholders in new EU member states with comparable experiences in transition from previous socialistic economies to modern market economies (Ericson, 1991; Furrer et al., 2010). The authors thus hypothesize:

H 1 - Significant differences exist in the evaluation of CSR's natural aspects between Lithuanian and Slovenian students.

Attitudes toward the social environment express humans' responses to social roles and norms expected from them by internal and external societies (Aguinis \& Glavas, 2012; Aupperle et al., 1985). People form their social attitudes from personal experiences and observations regarding their norms and roles in society (Eagly \& Chaiken, 1998; Minton \& Khale, 2014). Social attitudes in organizations "support actions that appear to further some social good, beyond the interests of the firm and that which is required by law" (McWilliams \& Siegel, 2000, p. 605), and "reduce social, business and legal risks of organizational actions on the basis of adjustment of organizational stakeholders' social characteristics to the expected social roles and norms of societies in which they participate" (Windsor, 2006, p. 96). For research we hypothesize:

H 2 - Significant differences exist in the evaluation of CSR's social aspect between Lithuanian and Slovenian students.

Attitudes toward the economic environment express humans' orientation toward achievement of the economic results and economic prosperity of them-selves, other people, groups, organizational, and societal environments (Windsor, 2006). The decisions of organizational stakeholder with regard to the needed and desirous orientation of economic attitudes are affected by: (a) economics, which defines the "discretionary and mandatory responsibility of enterprises" (Friedman, 1962, p. 16) and "predicts strong long-term social benefits of relatively unfettered markets operated by self-interested actors"
(Jensen, 2000, p. 39), and (b) the ethics of managers and investors as instrumentally defined, normatively commanded, and socially desirable (Carroll, 1999, p. 274). Consequently, studies have revealed contradictory results, from denying any meaning of natural and social goals (Friedman, 1962; Reinhardt et al., 2008) to disregarding economic goals in modern organizations.

The current patterns and states of organizational stakeholders' economic attitudes and the relations of these attributes with other links of the behavioral chain, have still not been comprehensively explained (McWilliams \& Siegel, 2000; Reinhardt et al., 2008). Studies by Crifo and Forget (2015) and Reinhardt et al. (2008), which introduce stakeholder's economic attitudes in different organizations presented a theoretical framework for authors' research of the situation of economic attitudes among students from considered samples. Thus, the authors propose the next hypothesis:

H 3 - Significant differences exist in the evaluation of CSR's economic aspect between Lithuanian and Slovenian students.

\section{The Effect of Economic Attitudes on Natural and Social CSR}

Waddock and Graves (1997) and Kitzmueller and Shimshack (2012) revealed foundations for associations between the attitudes toward CSR and the effects of attitudes on CSR-related behavior. Current behavioral studies of CSR mainly address natural and social attitudes; the specific characteristics and patterns of economic attitudes and their relation to other attitudes have received less attention in the literature (Reinhardt et al., 2008; Wang et al., 2016). How exactly organizational stakeholders' economic attitudes affect their natural and social CSR has still not been fully explained because of several unadjusted contentual and methodological issues (Carroll, 1999; Minton \& Khale, 2014).

The research trends of CSR have reported many overlapping and sometimes confusing conceptualizations of CSR's economic aspect due to the various schools of thought (Crifo \& Forget, 2015; Jensen, 2000). As scholars have revealed (Jensen, 2000; Reinhardt et al., 2008), studies of CSR's economic aspect are mutually interdependent with the personal perceptions of decision makers about associations between economic and CSR orientation, and between economic and other CSR attitudes in organizations' business. For example, Reinhardt et al. (2008) reported on the negative impact of an economic orientation toward CSR in accordance with traditional economic theory, which denies the meaning of CSR for organizations (Friedman, 1962). In contrast, McWilliams and Siegel (2000) have proposed a positive correlation between economic orientation and the achievement of CSR through the implementation of modern economic theories, emphasizing the prevailing meaning of CSR for modern organizations (Wang et al., 2016). These different perceptions could impact the definition of correlations between attitudes toward CSR, which consequently lead to presumptions about the prevailing, equal, or secondary importance of economic attitudes among CSR's attitudes (Stern, 2000; Wood, 2000). 
To gain clarity for research purposes, scholars have also developed different approaches to measuring the economic aspect of CSR (Aupperle et al., 1985; McWilliams \& Siegel, 2000). Leading studies have mainly addressed assessments of the economic aspect through financial and accounting-based measures (e.g., return on assets, return on equity) in terms of its justification and its impacts on other attitudes, CSR, and organizational results (Aupperle et al., 1985). From the perspective of how personal economic behavior affects CSR, the available literature provides no sufficient answers (Crifo \& Forget, 2015). Behavioral economics offers a promising solution by analyzing the effects of psychological, social, cognitive, and emotional factors on the economic decisions of individuals and institutions according to the economic aspect of CSR (Glavas, 2016; Waddock \& Graves, 1997).

In this study, the authors examine the economic aspect of CSR through students' behavior and perceptions of the orientation of their economic attitudes' and the relation of their economic attitudes to natural and social CSR's attitudes. To measure students' economic attitudes, the authors applied students' perceptions on the importance of "Primary concern for economic results" and "Devoting resources for CSR"; this reviews different students' economic opinions on the relationship between economics and CSR. Thus, the authors propose the next hypotheses:

H 4-A primary concern for economic results is negatively related to the natural and social aspect of CSR, as perceived by students.

H 5 - Devoting resources for CSR is positively related to the natural and social aspects of CSR, as perceived by students.

\section{Method}

\section{Sample and Procedure}

The sample included 159 business students from Lithuania and 212 business students from Slovenia. The respondents were selected using convenience sampling. In Lithuania the survey was done at the Faculty of Business Management, Vilnius Gediminos Technical University, and in Slovenia at the Faculty of Economics and Business at the University of Maribor. The survey was conducted in the academic year 2017/2018, and included business students from diverse years and fields of study. The surveying was conducted during classes, and students participated voluntarily.

The average age of Lithuanian students was 20.85 years and that of Slovenian students was 21.61 years, on average. The composition of the respondent sample in Lithuania was 30.8 percent males and 69.2 percent females, and in Slovenia 26.9 percent males and 73.1 percent females. With regard to the level of study, in the Lithuanian sample, 84.9 percent were bachelor students and 15.1 percent were master's students. In the Slovenian sample 78.8 percent were bachelor students and 21.2 percent master's students.

\section{Measures}

The authors used a modified version of the survey to examine values, relations in the workplace, and CSR (Ralston et al., 2011). The first part of the questionnaire includes 56 personal values, adapted from Schwartz's value survey
(Schwartz et al., 2012); the second part includes 25 items aimed to measure different aspects of CSR used by various international researchers (Furrer et al., 2010; Potocan et al., 2016; Ralston et al., 2011). In the last part, the authors asked participants about typical demographic data in business research. For this research, the authors used data from the second and third parts of the survey.

Students' attitudes toward CSR were measured with 25 items from a sub-scale of the questionnaire. The questionnaire was initially developed to assess the attitudes of employees towards CSR. The authors adapted the wording so that students could assess their attitudes toward CSR. Each item had nine Likert-type response choices $(1-$ Strongly agree to 9 - Strongly disagree). The sample items include: (1) allocate some of the organizational resources to philanthropic activities, and (2) worry first and foremost about maximizing profits, etc.

In line with the aims of this paper and according to the factorial analysis of the 25 items aimed at measuring various aspects of CSR, the authors would associate selected items with a concern for the economic, natural, and social aspects of CSR. Based on the results of factorial analysis, using varimax rotation, we established two variables to capture business students' attitudes toward the economic aspects of CSR and two variables aimed to capture the natural and social aspects of CSR.

Primary concern for economic results - This is considered as a measurable variable, where respondents were asked how they agreed with the statement: "Worry first and foremost about maximizing economic results."

Devoting resources for CSR - This includes expenditures for CSR, and is accurately and reliably represented with two items; organizations (1) pay their full financial obligation for using energy and natural resources; and (2) assume total (non)financial responsibility for environmental pollution caused by organizational activities. Cronbach's $\alpha$ for this scale was .658.

Concern for the natural aspect of CSR - This is accurately and reliably represented by three items, namely: organizations: (1) prevent environmental degradation caused by pollution and depletion of natural resources; (2) adopt formal programs in organizations to minimize the harmful impact of organizational activities on the environment; and (3) minimize the environmental impact of all organizational activities. Cronbach's $\alpha$ for this scale was .807 .

Concern for the social aspect of CSR - This is accurately and reliably represented by five items, namely: organizations (1) actively participate in philanthropic activities; (2) contribute actively to the welfare of our community; (3) help solve social problems; (4) play a role in society that goes beyond the mere generation of profits; and (5) train employees to act within the standards defined beyond normative obligations. Cronbach's $\alpha$ for this scale was .651.

In the current study internal reliability was highest for concern about the natural aspect of CSR (Cronbach's alpha $=.807)$. Although the internal reliabilities for devoting resources for CSR (.658) and concern for the social aspect of CSR (.651) were lower than the .70 regarded as acceptable by Nunnally (1978), the reliabilities obtained are comparable to those obtained in other studies using this 
instrument (Furrer et al., 2010; Potocan et al., 2016). Furrer et al. (2010) reported on attitudes toward CSR in eight European countries, and presented scale reliabilities for social CSR ranging between .50 and .74 , for economic CSR between .41 and .69 , and environmental CSR between .60 and .80. A study by Potocan et al. (2016), using this instrument, reported scale reliabilities for managers' concern for economic results as .611 , managers' environmental concern as .736 and enterprise environmental responsiveness as .659 . A study by Egri and Herman (2000), also using this instrument, considered internal reliabilities below .70 as acceptable in their study of the environmental sector.

The authors also modified the demographic section of the questionnaire, which included questions regarding age, gender, and level of study. Respondents indicated their age, gender, and level of study.

\section{Research Design and Analyses}

The focus of the authors' study was to determine whether differences existed in perceptions of CSR between Lithuanian and Slovenian business students and to examine the impact of the economic aspects on the natural and social aspects of CSR.

Accordingly, the authors' research was conducted in three steps: (1) In the first step, the authors outlined elements of descriptive statistics and zero-ordered correlations among variables of interest for the aggregated sample of Lithuanian and Slovenian business students, using SPSS 23. The authors used bivariate correlation analysis and Pearson's correlations coefficients. (2) In the second step, the authors used independent samples t-test in SPSS 23 to examine whether differences existed regarding the perceptions of Lithuanian and Slovenian business students on the economic, natural, and social aspects of CSR. (3) In the third step, the authors employed a structural equation modeling approach, using AMOS 18, to examine the relations between the economic aspects of CSR, considered through the lenses of one measurable variable, namely "primary concern for economic results" and one latent variable, namely "devoting resources for CSR," and the latent variables "concern for the natural aspect of CSR" and "concern for the social aspect of CSR." The research model for the authors' work is outlined in Figure 1.

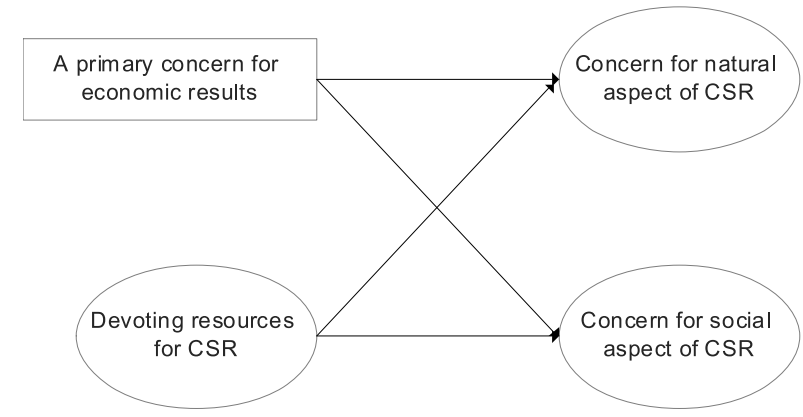

Figure 1. Research Model (Created by the Authors)

In terms of goodness-of-fit for the proposed research model (see Figure 1) the fit statistics were calculated for the four-factor measurement model, including "the primary concern for economic results"; "devoting resources for CSR"; "concern for the natural aspect of CSR"; and "concern for the social aspect of CSR." The fit statistics for the four-factor measurement model $\left(\chi^{2}(\mathrm{~N}=371, \mathrm{df}=41)=\right.$ 81.355, $\mathrm{p}<0.00 ; \mathrm{CFI}=.956 ; \mathrm{IFI}=.956 ; \mathrm{NFI}=.916$; RMSEA $=.052($ PCLOSE $=.415)$, indicated a good fit between the hypothesized model and the data (Byrne, 2010).

Bias - The possibility of bias exists due to the single source of data (Podsakoff et al., 2012). The authors estimated the common method variance by using the Harman single-factor technique in SPSS. With factorial analysis all the variables were loaded onto a single factor and constrained so there was no rotation (Podsakoff et al., 2012). The newly introduced common latent factor explains $23.46 \%$ of the variance, which is way below the acceptable $50 \%$ of the variance (Podsakoff et al., 2012).

In terms of multicollinearity among "primary concern for economic results," "devoting resources for CSR," "concern for the natural aspect of CSR" and "concern for the social aspect of CSR," the tolerance values are between .787 and .997; the VIF values are between 1.003 and 1.270. Tolerance values greater than .10, and VIF values below 10, are acceptable (Hair, Anderson, Tatham, \& Black, 1998, p. 14) and indicate that multicollinearity is not an issue in this research.

\section{Results and Discussion}

Table 1 shows the mean values, standard deviations, and zero-ordered correlations among the study variables for the aggregated sample of Lithuanian and Slovenian business students.

The results for the aggregated sample in Table 1 reveal associations which call for a deeper examination of: (a) the current state of CSR and its underlying aspects among Lithuanian and Slovenian business students, and (b) associations between the economic aspect and the natural and social aspects of CSR in the countries under consideration. First, the authors outlined the results of the independent samples t-test for Lithuania and Slovenia for four variables in the developed model (Table 2).

The natural, social, and economic CSR results in Table 2 enable us to draw the following conclusions. Students from Lithuania and Slovenia expressed high care for natural CSR. The current level of natural CSR in Lithuania has been affected by the development of CSR in the past decade (Vveinhardt \& Andriukaitiene, 2014) and the increasing understanding of natural CSR among business stakeholders (Dagiliene et al., 2014). Turning to Slovenia, care for the natural environment stems from the increasing orientation among enterprises toward natural CSR (Jelovac et al., 2011; Potocan et al., 2016).

Results from Table 2 regarding the concern for the natural aspect of CSR reveal significant differences between the countries under consideration (Lithuania: $\mathrm{M}=3.84$; Slovenia $=2.45 ; \mathrm{t}=8.88, p<0.001)$. This supports Hypothesis 1 .

In both countries, business students gave the greatest attention to social CSR. According to the current level of social CSR in Lithuania, studies may follow social expectations revealed by "Social policy of the EU" and "Civil Society in Lithuania" concerning social goals (Dagiliene et al., 2014; Vveinhardt \& Andriukaitiene, 2014). The current level of social CSR in Slovenia 
originated in "High social standards in Slovenia" (Furrer et al., 2010; Jelovac et al., 2011) and "social dialogue" aimed at the social goals of organizations (Jelovac et al., 2011; Potocan et al., 2016).

Results from Table 2 about concern for the social environment of CSR reveal significant differences between the countries studied (Lithuania: $\mathrm{M}=3.73$; Slovenia $=2.72$; $\mathrm{t}=8.87, p<0.001)$. This supports Hypothesis 2 .

Business students from both countries evaluated economic CSR as the least important for CSR. In Lithuania, the current level of economic CSR is astonishingly low according to the higher economic growth of the national economy (Pucetaite \& Pusinaite, 2015; Vveinhardt \& Andriukaitiene, 2014), and studies regarding the significant concern for the economic CSR of enterprises in Lithuania (Vveinhardt \& Andriukaitiene, 2014). Also, in Slovenia, where the orientation toward economic results enabled the successful development of enterprises before the economic crisis, and their fast recovery after the crisis, the opinion of business students concerning economic CSR does not follow economic and business patterns (Jelovac et al., 2011; Potocan et al., 2016).

Mean Values, Standard Deviations and Correlations among the Study Variables ${ }^{\text {a }}$ (Created by the Authors)

\begin{tabular}{|c|c|c|c|c|c|c|c|c|c|}
\hline Variable & $\mathbf{M}$ & SD & 1 & 2 & 3 & 4 & 5 & 6 & 7 \\
\hline Age & 21.28 & 1.44 & 1 & & & & & & \\
\hline Gender & 1.72 & .46 & $-.222 * * *$ & 1 & & & & & \\
\hline Level of study & 1.19 & .39 & $.727^{* * *} *$ & $-.174 * *$ & 1 & & & & \\
\hline Country & 1.57 & .49 & $.260^{* * *}$ & .036 & .078 & 1 & & & \\
\hline $\begin{array}{l}\text { Primary concern for } \\
\text { economic results }\end{array}$ & 3.92 & 1.95 & -.006 & -.057 & .089 & $-.279 * * *$ & 1 & & \\
\hline $\begin{array}{l}\text { Devoting resources for } \\
\text { CSR }\end{array}$ & 3.46 & 1.66 & -.089 & -.017 & -.027 & $-.296 * * *$ & .008 & 1 & \\
\hline $\begin{array}{l}\text { Concern for natural aspect } \\
\text { of CSR }\end{array}$ & 3.05 & 1.61 & $-.146 * *$ & -.054 & -.066 & $-.430 * * *$ & .036 & $.331 * * *$ & 1 \\
\hline $\begin{array}{l}\text { Concern for social aspect of } \\
\text { CSR }\end{array}$ & 3.16 & 1.19 & $-.105^{*}$ & $-.190 * * *$ & -.008 & $-.419 * * *$ & -.046 & $.459 * * *$ & $.462 * * *$ \\
\hline
\end{tabular}

${ }^{a} N=371 ; * p<.05 ; * * p<.01 ; * * * p<.001$

Table 2

Concern for Economic Results and Corporate Social

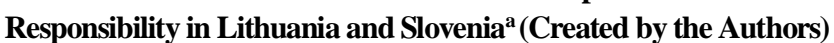

\begin{tabular}{llllll}
\hline Variables & \multicolumn{2}{l}{ Lithuania } & \multicolumn{2}{c}{ Slovenia } & \multicolumn{2}{c}{ t-test } \\
\cline { 2 - 5 } & Mean & SD & Mean & SD & \\
\hline $\begin{array}{l}\text { Primary concern } \\
\text { for economic } \\
\text { results }\end{array}$ & 4.55 & 1.86 & 3.45 & 1.89 & $5.58^{* * * *}$ \\
$\begin{array}{l}\text { Devoting } \\
\text { resources for }\end{array}$ & 4.03 & 1.64 & 3.04 & 1.55 & $5.95^{* * * *}$ \\
$\begin{array}{l}\text { CSR } \\
\text { Concern for }\end{array}$ & 3.84 & 1.62 & 2.45 & 1.32 & $8.88^{* * * *}$ \\
$\begin{array}{l}\text { natural aspect of } \\
\text { CSR }\end{array}$ & & & & & \\
$\begin{array}{l}\text { Concern for } \\
\text { social aspect of } \\
\text { CSR }\end{array}$ & 3.73 & 1.11 & 2.72 & 1.05 & $8.87^{* * * *}$ \\
\hline
\end{tabular}

$* p<.05 ; * * p<.01 ; * * * p<.001$

Results from Table 2 about the concern for the economic environment of CSR reveal significant differences in both countries about the primary concern for economic results (Lithuania: $\mathrm{M}=4.55$; Slovenia $=3.45 ; \mathrm{t}=$ $5.58, p<0.001$ ) and devoting resources for CSR (Lithuania: $\mathrm{M}=4.03$; Slovenia $=3.04 ; \mathrm{t}=5.95, p<0.001)$. This supports Hypothesis 3.

Next, we outline the results regarding the associations between the four considered variables in the research model for Lithuanian students (Figure 2) and Slovenian students (Figure 3).

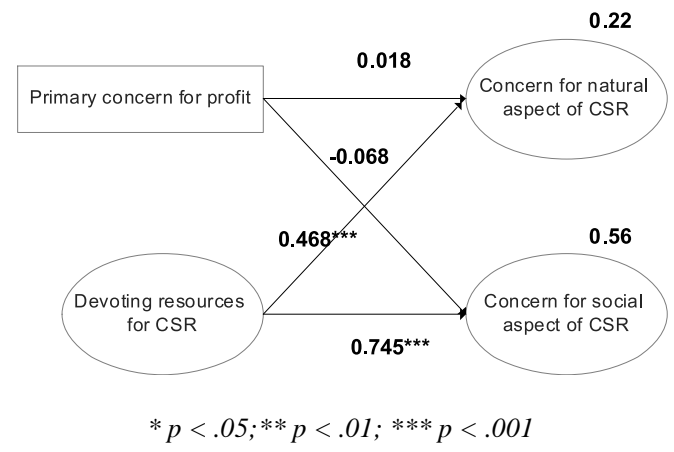

Figure 2. Path Analysis of Impact of the Economic Aspect of CSR on the Natural and Social Aspects of CSR for the Lithuanian Sample (Created by the Authors).

Data from Figure 2 show that the primary concern for the economic results has no significant influence on the natural and social aspects of CSR, whereas devoting resources for CSR significantly and positively impacts natural and social CSR.

The characteristics of the above-mentioned associations lead to the presumption that the Lithuanian students considered the primary concern for economic results and devoting resources for CSR as supporting the achievement of CSR. In agreement with these students are environmentalist authors, who have reported that caring for 
economic goals does not necessarily diminish the other two aspects of CSR (Crifo \& Forget, 2015; McWilliams \& Siegel, 2000).

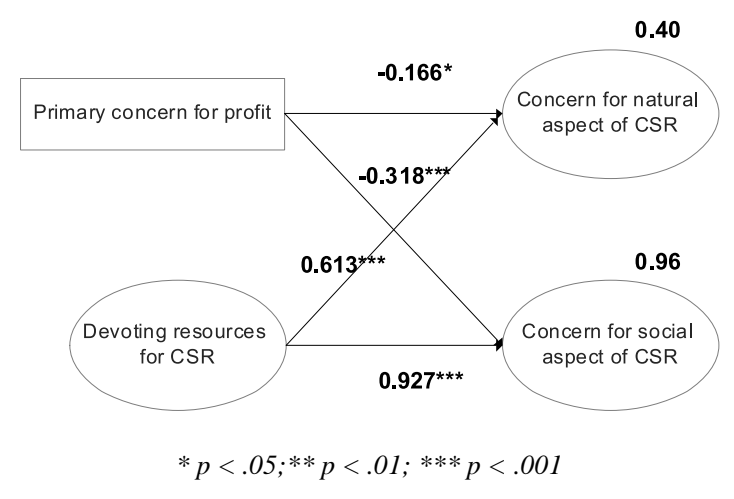

Figure 3. Path Analysis of impact of the Economic Aspect of CSR on the Natural and Social Aspects of CSR for the Slovenian Sample (Created by the Authors).

Results for Slovenia are in accordance with previous studies from Central Europe that reported the prevailing negative impact of the achievement of economic results on natural and social CSR (Furrer et al., 2010; Kemmelmeier et al., 2002; Potocan et al., 2016). The current situation is probably driven by the legacy of the past development (Potocan et al., 2016; Pucetaite \& Pusinaite, 2015).

Figure 3 indicates that a primary concern for economic results has a significant negative impact on the natural and social aspects of CSR, when devoting resources for CSR significantly and positively impacts natural and social CSR in the Slovenian sample.

Thus, the results present a contradictory understanding of economic CSR among students. The negative impact of the primary concern for the economic results on natural and social CSR expressed the students' "traditional understanding of CSR," where the primary striving for economic results reduces concern for the other two aspects (Friedman, 1962; Potocan et al., 2016; Reinhardt et al., 2008). Otherwise, the strong positive impacts of devoting resources for CSR on the other two CSRs show a more modern understanding of CSR, where care for economic goals can support and strengthen the achievement of the other CSR aspects (Jensen, 2000; Wang et al., 2016).

Results from Figure 2 (Lithuania) and Figure 3 (Slovenia) concerning the interplay between natural, social, and economic CSR outline the next conclusions.

Results on the impact of a primary concern for the economic results on the natural (Lithuania: $\beta=0.018, p$ $>0.05$; Slovenia: $\beta=\mathbf{- 0 . 1 6 6 ,} p<0.05$ ) and social aspects (Lithuania: $\beta=\mathbf{- 0 . 0 6 8}, p>0.05$; Slovenia: $\beta=\mathbf{- 0 . 3 1 8 ,} p<$ 0.001) of CSR reveal non-significant associations for Lithuania and significant associations for Slovenia. This suggests a rejection of Hypothesis 4 for Lithuania and confirmation of this hypothesis for Slovenia.

Results concerning the impact of devoting resources for CSR on the natural (Lithuania: $\beta=0.468, p<0.001$; Slovenia: $\beta=0.613, p<0.001)$ and social aspects (Lithuania: $\beta=0.745, p<0.001$; Slovenia: $\beta=0.927, p<$ 0.001 ) of CSR reveal significant associations for both countries. This supports Hypothesis 5 for Lithuania and Slovenia.

\section{Conclusions}

This research outlined the current state of CSR as perceived by business students in Lithuania and Slovenia, and emphasized the impact of the business students' economic attitudes on their perception of the natural and social aspects of CSR in both countries.

Focusing on the current state of CSR in the countries studied, the survey results show that the Slovenian business students perceived all three CSR aspects as significantly more important than their Lithuanian peers did, as seen in Table 2. These lower evaluations of CSR aspects by the Lithuanian participants confirm that several issues regarding CSR in Lithuania are still open. The greatest differences are related to concern for the natural and social aspects, while the lowest, but still significant, differences cover the students' perception of the economic aspect of CSR, considered through a primary concern for economic results and dedicating resources for CSR.

First, turning to the significant differences in perceiving the concern for the natural aspect of CSR, we may conclude that the current level of natural CSR in Lithuania was influenced by the relatively slow development of CSR in the past decade and the lack of understanding about the importance of CSR in the business environment. The current care for the natural environment in Slovenia may stem from the developed institutional framework for CSR in society.

Second, regarding the significant differences in concern for the social environment of CSR, we can summarize that the current level of social CSR in Lithuania was determined by the legacy of the previous socio-economic settings, which still impede further CSR development. Turning to Slovenia, a "consensus" among the key actors regarding enforcement of the social goals between organizations can be outlined.

Third, regarding the significant differences in concern for the economic environment of CSR, important differences in both countries regarding the primary concern for the economic results and devoting resources for CSR exist. These results are good indicators of the noteworthy recent progress in the development of CSR in Lithuania, since the primary concern for economic results is not in the forefront anymore, as it was in previous years, and has recently been replaced by concern for the social aspect of CSR. For Slovenia these findings are reflected through the successful development of the economy in the past decade.

Turning to the associations between the concern for the economic aspect of CSR, on the one hand, and the natural and social aspects of CSR, on the other hand, they reveal the following (see figures 2 and 3). Devoting resources for CSR demonstrates a similar positive effect on concern for the natural and social aspects of CSR in both countries. Inversely, the impact of the primary concern for profit showed different impacts on the natural and social aspects of CSR between the two countries studied. These research results led to the following findings. The non-significant influence of the primary concern for economic results on the concern for the natural and social aspects of CSR in the Lithuanian sample indicate that the concern for economic results is not considered an important aspect of CSR. Furthermore, one can argue that CSR has not been fully integrated into business operations in Lithuanian organizations, and that the understanding of CSR does not match "the traditional or the modern understanding" of 
CSR. For Slovenia, the results reveal that business students perceive CSR aspects and linkages between them in a traditional way, where a negative association between the primary concern for economic results and the concern for the natural and social aspects is outlined.

Regarding the positive associations between devoting resources for CSR, on the one hand, and the natural and social aspects of CSR, on the other hand, in both countries, we may argue that this is very promising for the further development of CSR in these countries. Such a state also reflects a foundation for resolving open issues regarding CSR in both economies and the wish to move CSR to a higher level.

On the basis of the examined articles and the results we obtained from our field study, we can outline the following implications. First, the findings provide an up-to-date state of business students' perceptions of CSR in Lithuania and Slovenia, which form the basis for future actions of various entities, in order to design relevant actions for the broader recognition of CSR among political and business actors in Slovenia, and omit existing barriers to further CSR development in Lithuania.

Second, turning to the organizational level, organizations in the future will have to actively shape CSR, especially those organizations having less advanced CSR. Thus, understanding the attitudes towards CSR of "newcomers" in organizations will be very beneficial, because the millennial generation will shortly surpass other generations in the workplace and because of the low commitment of the new generation to CSR issues.

Third, the authors' results provide fertile ground for implications in the educational sphere. The current generations of students prioritize their quest for rapid advancement, promotion, and good payment, while the commitment to CSR is not in the forefront of the younger generation. Thus, the educational system, from kindergarten to higher education, must play an active role in heightening the importance of CSR. For instance, higher education organizations, especially business schools, should make a significant curriculum change to include more CSR content.

This paper has several limitations. First, significant differences in students' perception of CSR between the former socialistic countries limit the possibility of broadly generalizing the findings to other emerging countries. Second, a self-assessment scale is used, according to which the students themselves assessed their perception of three aspects of CSR. Third, a sample of students was used since CSR has often been studied using student samples, although students may have perceptions about CSR aspects that differ from the perceptions of employees, due to their lack of experience of organizational practice. Fourth, a minor limitation is the use of the convenience sample selection method, which may have implications for the results. Such samples have a limited ability to represent the geographical distribution of respondents inside the country.

The following research directions are possible. First, the role of the social and "historical-transitional context" in the appreciation of CSR should be examined. Second, the perceived differences call for research to determine whether the findings can be replicated in other emerging countries. Third, it would also be beneficial to examine the role of personal values in shaping young individuals' attitudes toward CSR issues, due to the different priorities of younger generations about CSR issues in comparison with current employees. Scholars should also check whether millennials' typical characteristics are consistent across different cultures, which would clarify the reality.

\section{References}

Aguilera, R. V., Rupp, D. E., Williams, C. A., \& Ganapathi, J. (2007). Putting the s back in corporate social responsibility: A multilevel theory of social change in organizations. The Academy of Management Review, 32(3), 836-863. https://doi.org/10.5465/amr.2007.25275678

Aguinis, H. (2011). Organizational responsibility: Doing good and doing well. In S. Zedeck (Ed.), APA handbook of industrial and organizational psychology (Vol. 3, pp. 855-879). Washington: American Psychological Association. https://doi.org/10.1037/12171-024

Aguinis, H., \& Glavas, A. (2012). What we know and don't know about corporate social responsibility: A review and research agenda. Journal of Management, 38(4), 932-968. https://doi.org/10.1177/0149206311436079

Ajzen, I. (2005). Attitudes, personality, and behavior. Beckshire: Open University Press.

Aupperle, K. E., Carroll, A. B., \& Hatfield, J. D. (1985). An empirical examination of the relationship between corporate social responsibility and profitability. The Academy of Management Journal, 28(2), $446-463$. https://doi.org/10.2307/256210

Byrne, B. M. (2010). Structural equation modeling with AMOS. New York, NY: Routledge.

Campbell, J. L. (2007). Why would corporations behave in socially responsible ways? An institutional theory of corporate social responsibility. Academy of Management Review, 32(3), 946-967. https://doi.org/10.5465/amr.2007.25275684

Carroll, A. B. (1999). Corporate social responsibility: Evolution of a definitional construct. Business \& Society, 38(3), 268295. https://doi.org/10.1177/000765039903800303

Carroll, A. B., \& Shabana, K. M. (2010). The business case for corporate social responsibility: A review of concepts, research and practice. International Journal of Management Reviews, 12(1), 85-105. https://doi.org/10.1111/j.14682370.2009.00275.x

Crifo, P., \& Forget, V. D. (2015). The economics of corporate social responsibility: A firm-level perspective survey. Journal of Economic Surveys, 29(1), 112-130. https://doi.org/10.1111/joes.12055

Dagiliene, L., Leitoniene, S., \& Grencikova, A. (2014). Increasing business transparency by corporate social reporting: Development and problems in Lithuania. Inzinerine Ekonomika-Engineering Economics, 25(1), 54-61. https://doi.org/10.5755/j01.ee.25.1.2356 
Dahlsrud, A. (2008). How corporate social responsibility is defined: An analysis of 37 definitions. Corporate Social Responsibility and Environmental Management, 15(1), 1-13. https://doi.org/10.1002/csr.132

Davis, G., Whitman, M., \& Zald, M. (2008). The responsibility paradox. Stanford Social Innovation Review, 6(1), 31-37.

Dunlap, R. E., \& Mertig, A. G. (1990). American environmentalism: The U.S. Environmental movement, 1970-1990. Washington, DC: Taylor \& Francis.

Eagly, A., \& Chaiken, S. (1998). Attitude structure and function. In T. Gilbert, S. Fisk \& L. G. (Eds.), Handbook of social psychology (pp. 269-322). New York: McGowan-Hill.

EC (2018a). Country report Lithuania 2018 (commission staff working document). Available from internet: https://www.parlament.gv.at/PAKT/EU/XXVI/EU/01/40/EU_14096/imfname_10792639.pdf

EC (2018b). Country report Slovenia 2018 (commission staff working document). Available from internet: https://ec.europa.eu/info/sites/info/files/2018-european-semester-country-report-slovenia-en.pdf

Egri, C. P., \& Herman, S. (2000). Leadership in the North American environmental sector: Values, leadership styles, and contexts of environmental leaders and their organizations. Academy of Management Journal, 43(4), 571-604. https://doi.org/10.5465/1556356

Elkington, J. (2004). Enter the triple bottom line. In A. Henriques \& J. Richardson (Eds.), The triple bottom line: Does it all add up (pp. 1-16). London, United Kingdom: Earthscan.

Ericson, R. E. (1991). The classical soviet-type economy: Nature of the system and implications for reform. Journal of Economics Perspectives, 5(4), 11-27. https://doi.org/10.1257/jep.5.4.11

Friedman, M. (1962). Capitalism and freedom. Chicagao, IL: University of Chicago Press.

Furrer, O., Egri, C. P., Ralston, D. A., Danis, W., Reynaud, E., Naoumova, I., . . Furrer-Perrinjaquet, A. (2010). Attitudes toward corporate responsibilities in Western Europe and in Central and East Europe. Management International Review, 50(3), 379-398. https://doi.org/10.1007/s11575-010-0034-3

Glavas, A. (2016). Corporate social responsibility and organizational psychology: An integrative review. Frontiers of Psychology, 144(7). Retrieved from http://journal.frontiersin.org/article/10.3389/fpsyg.2016.00144/. https://doi.org/10.3389/fpsyg.2016.00144

Hair, J. F., Anderson, R. E., Tatham, R. L., \& Black, W. C. (1998). Multivariate data analysis with readings. Englewood Cliffs, NJ: Prentice-Hall.

Jelovac, D., Van Der Wal, Z., \& Jelovac, A. (2011). Business and government ethics in the 'new' and 'old' EU: An empirical account of public-private value congruence in Slovenia and The Netherlands. Journal of Business Ethics, 103(1), 127141. https://doi.org/10.1007/s10551-011-0846-5

Jensen, M. (2000). Value maximization and the corporate objective functions. In M. Beer \& N. Nohria (Eds.), Breaking the code of change (pp. 37-57). Boston: HSB Press. https://doi.org/10.2139/ssrn.220671

Kemmelmeier, M., Krol, G., \& Kim, Y. H. (2002). Values, economics, and proenvironmental attitudes in 22 societies. CrossCultural Research, 36(3), 256-285. https://doi.org/10.1177/10697102036003004

Kitzmueller, M., \& Shimshack, J. (2012). Economic perspectives on corporate social responsibility. Journal of Economic Literature, 50(1), 51-84. https://doi.org/10.1257/jel.50.1.51

McWilliams, A., \& Siegel, D. (2000). Corporate social responsibility and financial performance: Correlation or misspecification? Strategic Management Journal, 21(5), 603-609. https://doi.org/10.1002/(SICI)10970266(200005)21:5<603::AID-SMJ101>3.3.CO;2-V

Minton, E., \& Khale, L. (2014). Belief systems, religion, and behavioral economics. New York: Business Expert Press.

Ng, E. S. W., Schweitzer, L., \& Lyons, S. T. (2010). New generation, great expectations: A field study of the millennial generation. Journal of Business and Psychology, 25(2), 281-292. https://doi.org/10.1007/s10869-010-9159-4

Nunnally, J. (1978). Psychometric theory. New York: McGraw-Hill.

Podsakoff, P. M., MacKenzie, S. B., \& Podsakoff, N. P. (2012). Sources of method bias in social science research and recommendations on how to control it. Annual Review of Psychology, 63, 539-569. https://doi.org/10.1146/annurevpsych-120710-100452

Potocan, V., Nedelko, Z., Peleckiene, V., \& Peleckis, K. (2016). Values, environmental concern and economic concern as predictors of enterprise environmental responsiveness. Journal of Business Economics and Management, 17(5), 685700. https://doi.org/10.3846/16111699.2016.1202315

Pucetaite, R., \& Pusinaite, R. (2015). Corporate social responsibility in Lithuania: Fragmented attempts to respond to external pressure. In S. O. Idowu, R. Schmidpeter \& M. S. Fifka (Eds.), Corporate social responsibility in Europe: United in sustainable diversity (pp. 365-380). Cham: Springer International Publishing. https://doi.org/10.1007/9783-319-13566-3_20

Ralston, D. A., Egri, C. P., Reynaud, E., Srinivasan, N., Furrer, O., Brock, D., . . Wallace, A. (2011). A twenty-first century assessment of values across the global workforce. Journal of Business Ethics, 104(1), 1-31. https://doi.org/10.1007/s10551-011-0835-8

Reinhardt, F., Stavins, R., \& Vietor, R. (2008). Corporate social responsibility through an economic lens. Review of Environmental Economics and Policy, 2(2), 219-239. https://doi.org/10.1093/reep/ren008 
Salciuviene, L., Hopeniene, R., \& Dovaliene, A. (2016). Perceived corporate social responsibility and its implementation in practice: The case of Lithuanian small and medium-sized enterprises. Inzinerine Ekonomika-Engineering Economics, 27(4), 479-490. https://doi.org/10.5755/j01.ee.27.4.14713

Schrempf-Stirling, J., Palazzo, G., \& Phillips, R. A. (2016). Historic corporate social responsibility. Academy of Management Review, 41(4), 700-719. https://doi.org/10.5465/amr.2014.0137

Schultz, P. W., Gouveia, V. V., Cameron, L. D., Tankha, G., Schmuck, P., \& Franek, M. (2005). Values and their relationship to environmental concern and conservation behavior. Journal of Cross-Cultural Psychology, 36(4), 457-475. https://doi.org/10.1177/0022022105275962

Schwartz, S. H., Cieciuch, J., Vecchione, M., Davidov, E., Fischer, R., Beierlein, C., . . Konty, M. (2012). Refining the theory of basic individual values. Journal of Personality and Social Psychology, 103(4), 663-688. https://doi.org/10.1037/a0029393

Slaper, T. F., \& Hall, T. J. (2011). The triple bottom line: What is it and how does it work? Indiana Business Review, 86(1), 4-8.

Stern, P. C. (2000). Toward a coherent theory of environmentally significant behavior. Journal of Social Issues, 56(3), 407424. https://doi.org/10.1111/0022-4537.00175

UN (2017). World economic situation and prospects (WESP) 2017. New York: United Nations, Department of Economics and Social Affairs.

Vasiljeviene, N., \& Vasiljev, A. (2005). Lithuania - the roadmap: From confrontation to consensus In A. Habisch, M. Wegner, R. Schmidpeter \& J. Jonker (Eds.), Corporate social responsibility across Europe (pp. 183-193). Berlin, Heidelberg: Springer Berlin Heidelberg. https://doi.org/10.1007/3-540-26960-6_15

Vveinhardt, J., \& Andriukaitiene, R. (2014). Social responsibility discourse in empirical and theoretical Lithuanian scientific studies. Inzinerine Ekonomika-Engineering Economics, 25(5), 578-588. https://doi.org/10. 5755/j01.ee.25.5.4898

Waddock, S. A., \& Graves, S. B. (1997). The corporate social performance-financial performance link. Strategic Management Journal, 18(4), 303-319. https://doi.org/10.1002/(SICI)1097-0266(199704)18:4<303::AIDSMJ869>3.0.CO;2-G

Wang, H., Tong, L., Takeuchi, R., \& George, G. (2016). Corporate social responsibility: An overview and new research directions: Thematic issue on corporate social responsibility. Academy of Management Journal, 59(2), 534-544. https://doi.org/10.5465/amj.2016.5001

Windsor, D. (2006). Corporate social responsibility: Three key approaches. Journal of Management Studies, $43(1)$, 93-114. https://doi.org/10.1111/j.1467-6486.2006.00584.X

Wood, W. (2000). Attitude change: Persuasion and social influence. Annual Review of Psychology, 51, 539-570. https://doi.org/10.1146/annurev.psych.51.1.539

The article has been reviewed.

Received in July 2018; accepted in June 2019. 